\title{
The Gly1057Asp polymorphism in IRS-2 interacts with obesity to affect beta cell function
}

\author{
N. Stefan ${ }^{1}$ • A. Fritsche ${ }^{1}$ F. Machicao ${ }^{1}$ O. Tschritter $^{1}$ H. U. Häring ${ }^{1}$ M. Stumvoll ${ }^{1}$ \\ ${ }^{1}$ Department of Internal Medicine, Division of Endocrinology, Metabolism and Pathobiochemistry, University of Tübingen, \\ Tübingen, Germany
}

\section{Diabetologia (2004) 47:759-761}

Unfortunately, Dr Stumvoll's name was printed incorrectly as 'Stumvogel'.
Published online: 10 December 2004

(C) Springer-Verlag 2004

DOI 10.1007/s00125-004-1622-1

The online version of the original article can be found at http://dx.doi.org/10.1007/s00125-003-1302-6

Dr. N. Stefan $(-)$

Department of Internal Medicine,

Division of Endocrinology,

Metabolism and Pathobiochemistry,

University of Tübingen, Tübingen, Germany

E-mail: norbert.stefan@med.uni-tuebingen.de 